\title{
Note
}

LisA Hopkins

\section{Venice in 'Tis Pity She's a Whore}

The Caroline dramatist John Ford, like a number of his contemporaries and predecessors, shows a clear interest in Italy in a number of his works: The Fancies, Chaste and Noble is set in Siena, The Lady's Trial in Genoa, and Love's Sacrifice in Pavia, while his most famous play, 'Tis Pity She's a Whore, is set in Parma, and includes characters who have visited Livorno and Bologna. In Giuseppe Patroni Griffi's film of 'Tis Pity, however, Soranzo, unable to interest his new bride Annabella in consummating their relationship, says 'What you need is a distraction - to see yourself in a new and different setting, in more cheerful rooms ... You shall see Venice.' ${ }^{1}$ This visit has no warrant in the original text, but at an early stage of the play, while Soranzo is still a suitor for Annabella, we see him alone 'in his study, reading a book', which he later tells us contains Jacopo Sannazaro's encomium on Venice. Soranzo apparently both quotes from this poem and proposes a rewriting which would praise Annabella rather than Venice: ${ }^{2}$

'Love's measure is extreme, the comfort pain,

The life unrest, and the reward disdain.'

What's here? Look't o'er again: 'tis so, so writes

This smooth licentious poet in his rhymes.

But Sannazar, thou liest, for had thy bosom

Felt such oppression as is laid on mine,

Thou wouldst have kissed the rod that made the smart.

To work then, happy Muse, and contradict

What Sannazar hath in his envy writ:

'Love's measure is the mean, sweet his annoys,

His pleasures life, and his reward all joys.' 
Had Annabella lived when Sannazar

Did in his brief encomium celebrate

Venice, that queen of cities, he had left

That verse which gained him such a sum of gold,

And for only look from Annabell

Had writ of her, and her diviner cheeks.

The Revels note, however, points out that the lines attributed to Sannazaro have not been identified; although he did write an epigram 'On the marvelous city of Venice' and another 'On the flags of the Venetians', neither bears any relation to anything in Soranzo's speech, ${ }^{4}$ and indeed Sannazaro was in fact associated almost exclusively with Naples. Why then does Ford refer to him in this context?

One possibility is Sir Philip Sidney's interest in him. As Jane KingsleySmith remarks,

Sidney probably learned Italian as a child, and from the age of 10 his gentleman companion was Lodowick Bryskett, originally Lodovico Bruschetto, born in London to Italian parents. With Bryskett, Sidney travelled extensively in Europe from 1572 to 1575, including sojourns in Padua and Venice, as well as brief visits to Florence and Genoa. Letters written during this time refer to him improving his written Italian through a series of translation exercises. He was also busy buying Italian books, including Guicciardini's history of Italy, Girolamo Ruscelli's Imprese Illustri, and perhaps an illustrated copy of Sannazaro's Arcadia. ${ }^{5}$

Whenever he acquired a copy, Sidney was certainly aware of Sannazaro. David Kalstone notes that 'Sidney, considering the problem of diction in pastoral verse, quite naturally refers his readers to "Theocritus in Greeke, Virgil in Latine, [and] Sanazara in Italian"'; observing that 'It is in the eclogues of his Arcadia that Sidney draws most noticeably upon Sannazaro', Kalstone suggests that 'Sidney's poem must be taken, I think, as a criticism of the uncomplicated happiness of Sannazaro's Arcadia'. ${ }^{6}$

If Sidney was interested in Sannazaro, Ford, in turn, was interested in Sidney. In 1909 Stuart Sherman suggested that behind the fictional love story of Penthea and Orgilus in Ford's play The Broken Heart lay the real-life love story of Sir Philip Sidney and Penelope Devereux, the sister of the Earl of Essex and the Stella of Astrophel and Stella, who had been forced by her family to marry 
Robert, Lord Rich, whom she detested; amongst the various other pieces of evidence he adduced, Sherman pointed out that in his elegy for Sidney, Astrophel, Spenser imagined the two lovers as transformed into one flower, whose name is Starlight, Astrophel, or Penthia. ${ }^{7}$ By 1943, this view had become orthodoxy: Thomas Marc Parrott and Robert Hamilton Ball in A Short View of Elizabethan Drama baldly asserted that "The "truth" to which Ford alludes is the well known story of Philip Sidney's passion for Penelope Devereux'. ${ }^{8}$ Similarly Cyril Falls, in 'Penelope Rich and the Poets: Philip Sidney to John Ford', simply accepted the similarity of the events of The Broken Heart to the story of Penelope and Sidney and further noted the fact that John Stradling, who was a cousin of Ford's, wrote a Latin eulogy on what Penelope's second husband Lord Mountjoy had achieved in Ireland. ${ }^{9}$ Verna Ann Foster and Stephen Foster offer a slightly modified version of this equation when they suggest that Penthea and Orgilus can be perceived as Penelope and Sidney/ Mountjoy because Ithocles is readily identifiable as Essex. ${ }^{10}$

The story of Orgilus and Penthea certainly does have elements in common with that of Sidney and his Stella, while the names of Ford's characters may well seem to echo those of Argalus and Parthenia, who feature in one of the numerous sub-plots of the new Arcadia, and 'the general indebtedness of Ford's play to Sidney's Arcadia has been noticed'. ${ }^{11}$ Ford's borrowings from Sidney are certainly extensive and sustained. In both The Broken Heart and the Arcadia, events unfold against the backdrop of a riddling oracle which has foretold the fall from power of the present royal family. In Sidney, too, the King of Laconia is called Amiclas, matching Ford's Amyclas; Parthenia when deformed refuses to marry Argalus, just as Penthea refuses Orgilus, though Parthenia later, in disguise, tries to trick Argalus into marrying her with a ring, rather as Calantha asserts her wedding to Ithocles.

Conceivably, then, the memory of Sidney prompted that of Sannazaro. The reasons why Ford should wish to refer to Venice are, I think, simpler. In fact all we see of Venice in the Patroni Griffi film is statuary, an interior scene, and the consummation. The point of the visit Soranzo proposes in the film, however, is not to admire the scenery but to capitalize on the erotic image of Venice, which he hopes will induce Annabella to consummate the marriage. This view of Venice appears for instance in Shakespeare's Othello:

IAGO ... To kiss in private?

othello An unauthorized kiss! 
IAGO Or to be naked with her friend in bed

An hour or more, not meaning any harm?

$(4.1 .2-5)^{12}$

Othello was a play to which Ford recurred obsessively, borrowing motifs and/ or basic plot structure from it for both The Lady's Trial and Love's Sacrifice, and at least glancing at it in the jealousy scenes of 'Tis Pity.

Moreover, although Sannazaro was not a name associated with Venice, that of Annabella's husband, Soranzo, certainly was. In the fourteenth century one Giovanni Soranzo was doge of Venice, succeeding in 1312; more to the point, though, was the fact that the Venetian ambassador to England in the early 1630s, the time when 'Tis Pity was probably being composed, was also called Giovanni Soranzo. This Soranzo seems to have arrived in England in July 1629, since on 21 June 1631 he says 'On the 15th July next I shall have served for two years in this charge ... I therefore petition you to choose my successor. ${ }^{13}$ The doge and senate duly obliged, and on 6 February 1632 Soranzo and his successor, Vincenzo Gussoni, who had previously been Venetian ambassador to the Netherlands, sent a joint despatch noting the latter's arrival. ${ }^{14}$ On 6 March 1632 Soranzo reports that 'I ... am quite ready to cross the sea and nothing prevents my journey except the wind, which keeps obstinately contrary, so that it has not yet been possible to get my baggage away from these shores'. Since by 26 March Gussoni is reporting alone instead of through the joint reports the two have previously submitted, ${ }^{15}$ Soranzo had presumably moved on to his next post in France. During his four years in London he made the acquaintance of several of Ford's early dedicatees: on 20 February 1632 he notes that 'Yesterday the Earls of Pembroke and Arundel came one after the other, on purpose to visit us at this embassy', 16 and he also knew Lord Craven, dedicatee of The Broken Heart. He dismisses Craven, however, as a 'thoughtless young man', ${ }^{17}$ and indeed he struggled to like much about London at all, wrestling unhappily with the spelling of Harwich (Aruich), Guernsey (Garnasie), and Falmouth (Falmuz), complaining on 8 November 1630 of 'a chronic illness which I have contracted in this Northern climate ... my discomfort becomes greater every day', ${ }^{18}$ and lamenting on 2 August 1630 that 'I have never been so harassed as I am at present owing to the overbearing behaviour of this barbarous and unreasonable race. ${ }^{19}$ If Ford, through his dedicatees, either knew him or knew of him, his choice to give his name to an unattractive character is perhaps not surprising. 
As well as knowing some of Ford's dedicatees, Soranzo also took a considerable interest in another figure who I think is potentially relevant to 'Tis Pity She's a Whore and its mention of both Sannazaro and Venice, Sir Kenelm Digby. Soranzo mentions him repeatedly between 1629 and 1631 and writes on 27 December 1630 of 'Sir Kenelm Digby, who was at one time a pirate in the Mediterranean, and who let your Serenity's subjects feel the unlawful effects of his robberies. Moved by ambition he has recently abandoned the Catholic faith and become a Protestant. ${ }^{20}$ Intriguingly, a list of books which George Digby, earl of Bristol, inherited from Sir Kenelm Digby includes a copy of 'L'Arcadie de Messire Jacques Sannazar'. ${ }^{21}$ We do not know when Sir Kenelm acquired it, but the Dictionary of National Biography $(D N B)$ notes that 'Late in 1632 his Oxford friend Thomas Allen died and left him a huge collection of mansucripts ... and all the printed books he fancied, apart from special bequests. ${ }^{22}$ Ford had family connections with Sir Kenelm Digby through his mother's relatives, the Stradlings of South Wales: Matthew Steggle notes that in 1629 Richard Holford sold parts of the same plot of land to Sir Edward Stradling and Sir Kenelm Digby and in 1630 they jointly petitioned the king for permission to develop it, ${ }^{23}$ and on Digby's Mediterranean voyage his vice-admiral was the same Sir Edward Stradling, ${ }^{24}$ whom his most recent biographer describes as 'an old friend'. ${ }^{25}$ Henry A. Bright also notes that 'Sir Kenelm Digby's second son, John Digby ... was married first to a daughter of the Earl of Arundel', ${ }^{26}$ who had been an early dedicatee of Ford's, and it is perhaps also worth observing that Ford himself actually refers to Sir Kenelm Digby's ancestor, Sir John Digby, in Perkin Warbeck, where we hear of 'Digby, the Lieutenant of the Tower' (5.2.119). ${ }^{27}$

When his wife, the beautiful Venetia Stanley, died suddenly in her sleep on 1 May 1633, Kenelm Digby wrote an elegy for her which explicitly compared her to the city of Venice: 'What Trauelers of machles VENICE say, / Is true of thee Admyr'd VENECIA'. ${ }^{28}$ Digby noted that Venetia acquired her unusual name because she was born on St Venetia's Day, ${ }^{29}$ but for him it also clearly associates her with the city of Venice. 'Tis Pity She's a Whore also dates from 1633, though because it has no Stationers' Register entry it is impossible to know whether it belongs early or late in the year. Yet Ford might have been interested in the story of Venetia and Kenelm Digby, and in Venetia's death, for several reasons. First, I have already suggested elsewhere that 'Tis Pity's representation of Giovanni and Annabella shares something of the spirit of Digby's enquiry into folie à deux. ${ }^{30}$ Second, Venetia was the daughter of Sir Edward Stanley of Tong and his wife Lucy Percy, aunt of Ford's dedicatee 
the earl of Northumberland. Most notably, though, R.T. Petersson notes that 'The love affair of Kenelm and Venetia attracted so much public interest that James Shirley seems to have used it as the theme of his tragi-comedy The Wedding', and that Kenelm Digby himself told their story in his memoirs, fictionalized as Theagenes and Stelliana:

This odd history of himself and Venetia, which spans about a decade of their lives, is the strangest mixture of Arcadian love, heroic exploits, shallow philosophy, baroque fantasy, and special pleading for a lady's reputation, ever to be written down. Of concrete detail almost nothing is to be found in it, and of actual names, places, and dates, nothing at all. ${ }^{31}$

This work, which Digby wrote in 1628, in itself links intertextually with Sidney's - Vittorio Gabrieli notes that 'Stelliana probably stems from a contamination of Sidney's Stella with the maiden family name of Lady Digby', ie, Stanley, while Henry Rich, son of Sidney's Stella, is represented as the Earl of Arcadia. ${ }^{32}$

Ford seems to have known of Private Memoirs, despite the fact that it was not published: Gabrieli suggests an echo of it in The Lover's Melancholy, and it certainly foreshadows the plot of The Broken Heart, since Stelliana initially refuses Theagenes on the grounds that she had agreed to marry Mardontius and 'she would never suffer that one man should possess her, and another such a gage of a former, though half-constrained, affection', just as Penthea says she will never marry Orgilus even if Bassanes should die. ${ }^{33}$ Stelliana's father, moreover, is called Nearchus, ${ }^{34}$ the name of an important character in The Broken Heart, Theagenes's mother Arete sends him to Athens to separate him from Stelliana ${ }^{35}$ just as Orgilus ostensibly travels there to forget Penthea, and Theagenes leaves Athens because of plague ${ }^{36}$ just as Orgilus says he has had to do.

It is, therefore, worth noting that Stelliana tells Theagenes she loves him 'as much as ever sister did a brother' and that we hear, in typically Fordian imagery, of 'such a flood of tears, true witnesses of her bleeding heart'. ${ }^{37}$ Gabrieli notes that J.G. Nicholls suggested that the real-life equivalent of Digby's Mardontius was John Mordaunt, earl of Peterborough, ${ }^{38}$ who was the dedicatee of 'Tis Pity She's a Whore, a suggestion with which Digby's most recent biographer concurs, ${ }^{39}$ and some other suggestive similarities exist between Ford's play and Digby's life. $D N B$ notes that according to his own account, when Marie de' Medici fell in love with him 'Digby gave out that he 
was dead and fled south, taking ship to Leghorn', like Richardetto in 'Tis Pity (and like Richardetto he also dabbled in medicine). ${ }^{40}$ Like Ford's Giovanni, Digby was interested in the interiors of bodies: he dissected snakes, paying particular attention to their hearts, and also took detailed notes on the postmortem examination of Venetia, and his interest in embryos was such that $D N B$ observes that 'he has been called the father of modern embryology' 41 He was also, like Giovanni, interested in what was contained within the heart, writing in one of his poems,

Look in my heart wherin as in a shrine

The liuelie picture of thy beautie lyes

Or if thy harmles modestie think shame

To look upon the horrours of my heart

Look on these lines and looking sie in them

The trophie of thy beautie and my smart. ${ }^{42}$

Such interest is perhaps hardly surprising given the anecdote which Aubrey recounts of the execution of Digby's father:

when Sir Everard Digby was executed 'Holding up the heart on his sword the executioner then uttered the customary phrase: "Here is the heart of a traitor!" A macabre report goes with these last moments. According to John Aubrey, Sir Everard answered the executioner with the words, "Thou liest!" 43

Whatever the truth may have been, Kenelm Digby certainly did look into Venetia's heart, noting that 'When she was opened, her heart was founde perfect and sounde, a fitt seate for such a courage as she had when she liued; wch surely was beyond all that euer I knew: it neuer stooped to a lowe or meane action or thought' 44 and later speculating that 'her heart that was the seate of goodnesse, truth and vertue, hath now nothing in it but peraduenture some presumptuous worme feeding on the middle of it'. 45 Digby also sounds like Giovanni when he speculates at great length on 'the content we should haue in one an other in the other world'. ${ }^{6}$ In a letter written after Venetia's death, Digby observed that 'all my lettered men that I had about me, I haue licensed'. 47 Seeking to link Ford with such a group would obviously be the wildest speculation, and proving that 'Tis Pity has anything to do with these potential resonances would be impossible. A perhaps intriguing possibility, nonetheless, is that in associating Sannazaro with Venice, Ford may have 
been partly prompted by having encountered a copy of Sannazaro's work in the possession of a man whose wife was named Venetia.

\section{Notes}

1 Tis Pity She's a Whore, dir. Giuseppe Patroni Griffi, 1971.

2 This use of quotation from earlier writers can be compared with Gervase Markham and Lewis Machin's The Dumb Knight, in which Precedent quotes from Venus and Adonis. Ford certainly knew The Dumb Knight, since it is clearly a source for his play The Queen.

3 John Ford, 'Tis Pity She's a Whore, ed. Derek Roper (Manchester, 1975).

4 Jacopo Sannazaro, Latin Poetry, trans. Michael C.J. Putnam (Cambridge, MA, 2009), 279, 323.

5 Jane Kingsley-Smith, 'Sidney, Cinthio, and Painter: A New Source for the Arcadia', Review of English Studies 57 (2006), 171.

6 David Kalstone, 'The Transformation of Arcadia: Sannazaro and Sir Philip Sidney', Comparative Literature 15.3 (1963), 234, 244, 249.

7 Stuart P. Sherman, 'Stella and The Broken Heart', PMLA 24.2 (1909), 285.

8 Thomas Marc Parrott and Robert Hamilton Ball, A Short View of Elizabethan Drama (New York, 1943), 242.

9 Cyril Falls, 'Penelope Rich and the Poets: Philip Sidney to John Ford', Essays by Divers Hands 28 (1956), 130.

10 Verna Ann Foster and Stephen Foster, 'Structure and History in The Broken Heart: Sparta, England, and the "Truth", English Literary Renaissance 18.2 (1988), 315, 312, 318-19, 313, 305.

11 John Ford, The Broken Heart, ed. Brian Morris (London, 1965), Introduction, xi.

12 William Shakespeare, Othello, ed. E.A.J. Honigmann (London, 1997).

13 Allen B. Hinds (ed.), Calendar of State Papers Relating to English Affairs in the Archives of Venice, 38 vols (London, 1919), 22.508-21. http://www.british-history .ac.uk/report.aspx?compid=89284\&strquery=Giovanni\%20Soranzo.

14 Ibid, 22.583-94.

15 Ibid, 22.594-603.

16 Ibid, 22.583-94.

17 Ibid, 22.559-86.

18 Ibid, 22.434-42.

19 Ibid, 22.383-96.

20 Ibid, 22.442-54. 
21 Bibliotheca Digbeiana, sive, Catalogus librorum in variis linguis editorium quos post Kenelmum Digbeium eruditss. virum possedit illustrissimus Georgius Comes Bristol nuper defunctus ... (London, 1680). Note of course that Digby was not the only man in London known to possess a volume of Sannazaro: the author was also listed among the books mentioned in the will of John Florio. See Lukas Erne, Beyond the Spanish Tragedy: A Study of the Works of Thomas Kyd (Manchester, 2001), 194.

22 Michael Foster, 'Sir Kenelm Digby (1603-1665)', Oxford Dictionary of National Biography (Oxford and New York, 2004-), doi:10.1093/ref:odnb/7629.

23 Matthew Steggle, Richard Brome: Place and Politics on the Caroline Stage (Manchester, 2004), 39.

24 R.T. Petersson, Sir Kenelm Digby, The Ornament of England, 1603-1665 (London, 1956), 92.

25 Roy Digby Thomas, Digby: The Gunpowder Plotter's Legacy (London, 2001), 81.

26 Henry A. Bright, Poems from Sir Kenelm Digby's Papers in the Possession of Henry A. Bright (London, 1877), i.

27 John Ford, Perkin Warbeck, in Marion Lomax (ed.), 'Tis Pity She's a Whore and Other Plays (Oxford, 1995).

28 'An Elegie in Remembrance of the Lady VENECIA DIGBY', in Bright, Poems from Sir Kenelm Digby's Papers, 17.

29 Vittorio Gabrieli, 'A New Digby Letter-Book: "In Praise of Venetia", The National Library of Wales Journal 9.2 (1955), 135.

30 See my 'John Ford's 'Tis Pity She's a Whore and Early Diagnoses of Folie à Deux', Notes and Queries 41.1 (1994), 71-4.

31 Petersson, Sir Kenelm Digby, 43.

32 Kenelm Digby, Private Memoirs. Loose Fantasies, ed. Vittorio Gabrieli (Rome, 1968), 101.

33 Ibid, 10 n., 186-7 n., 121.

34 Ibid, 11.

35 Ibid, 41.

36 Ibid, 43.

37 Ibid, 144, 124-5.

38 Ibid, 29.

39 Thomas, Digby: The Gunpowder Plotter's Legacy, 67.

40 Foster, 'Sir Kenelm Digby (1603-1665)'.

41 Ibid.

42 Bright, Poems from Sir Kenelm Digby's Papers, 13.

43 Petersson, Sir Kenelm Digby, 23.

44 Gabrieli, 'A New Digby Letter-Book' (1955), 134. 


\section{LisA Hopkins}

45 Vittorio Gabrieli, 'A New Digby Letter-Book: "In Praise of Venetia"', The National Library of Wales Journal 9.4 (1956), 455.

46 Gabrieli, 'A New Digby Letter-Book' (1955), 139.

47 Gabrieli, 'A New Digby Letter-Book' (1956), 447. 